\title{
Holding Polluters Accountable in Times of Climate and COVID Risk: The Problems with "Emergency" Enforcement Waivers $\dagger$
}

\author{
VICTOR B. FLATT*
}

\section{TABLE OF CONTENTS}

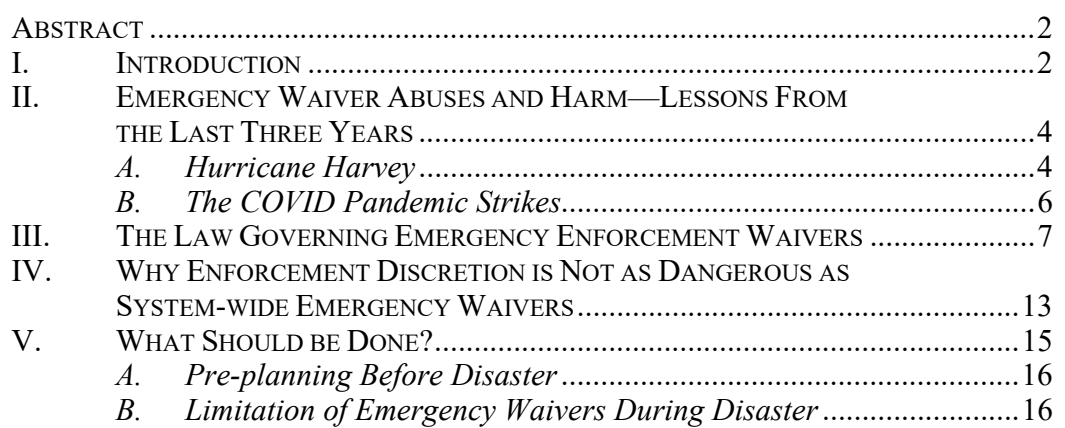

$\dagger \quad$ 12th Annual Lesley K. McAllister Symposium on Climate \& Energy Law “Climate Risk and Resilience: Lessons from COVID-19".

* (C) 2021 Victor B. Flatt. Dwight Olds Chair in Law and Faculty Co-Director, Environment, Energy, and Natural Resources (EENR) Center, University of Houston Law Center. The author would like to thank his Research Assistant, Colton Kiernan, for his assistance on this Article, and Victoire Marqué and other editors at the San Diego Journal of Climate \& Energy Law. 


\begin{abstract}
One of the first actions of the Environmental Protection Agency after the declaration of the COVID-19 crisis in mid-March 2020 was to announce that it would relax its enforcement policies with respect to environmental reporting and violations during the time of the pandemic. Ostensibly this was to ensure that regulated entities were not penalized by their inability to have inspectors on the front lines to ensure that substantive permit and monitoring requirements were followed. Taking their lead from the EPA, many states announced that they were following suit.

EPA always has discretion in terms of enforcement, but in making a blanket announcement, the agency created the space for substantial pollution and health risk from lack of adequate compliance in the regulated communities. It is hard to know what harms exist when reporting requirements are waived. This also sent the message that environmental protection is not a "critical function" which it should be at all times.

After climate induced disasters, federal and state agencies have done the same thing, abusing the "emergency" exemption privileges to give a broad non-compliance pass to regulated industries.

The uproar of the enforcement pause during the COVID-19 epidemic has shown a light on the abuse of enforcement discretion in disasters which are becoming more frequent with climate change.

This Article examines the legal basis of emergency exemptions, provides examples of how they have been abused in climate related disasters and the COVID -19 epidemic, and proposes solutions to curtail the abuse of these exemptions while still accounting for genuine emergency conditions.
\end{abstract}

\title{
I. INTRODUCTION
}

Thousands of oil and gas operations, government facilities and other sites won permission to stop monitoring for hazardous emissions or otherwise bypass rules intended to protect health and the environment because of the coronavirus outbreak, The Associated Press has found.

The result: approval for less environmental monitoring at some Texas refineries and at an army depot dismantling warheads armed with nerve gas in Kentucky, manure piling up and the mass disposal of livestock carcasses at farms in Iowa and Minnesota, and other risks to communities as governments eased enforcement over smokestacks, medical waste shipments, sewage plants, oilfields and chemical plants.

The Trump administration paved the way for the reduced monitoring on March 26 after being pressured by the oil and gas industry, which said lockdowns and social distancing during the pandemic made it difficult to comply with anti-pollution rules. States are responsible for much of the oversight of 
federal environmental laws, and many followed with leniency policies of their own. ${ }^{1}$

COVID-19 can rightfully take its place among terrible disasters that have affected the United States. Like climate change, COVID-19 exacerbated pre-existing health conditions, increasing death and impacting the public health. ${ }^{2}$ And like climate change linked disasters, COVID-19 resulted in "emergency" health and safety enforcement waivers, from the EPA, and with EPA's tacit encouragement, from the states. As with many emergency waivers, it isn't clear if this emergency waiver was necessary, and we will never fully know what harm resulted from this waiver.

Worse yet, as we have seen with the waivers from COVID, emergency waivers and enforcement problems can build off of each other, creating synergistic harms to public health. Researchers found that with the EPA's enforcement relaxation due to COVID, that harmful air pollutants (such as particulates and ozone) rose in heavily industrialized areas. ${ }^{3}$ These areas in turn saw a spike in daily death rates from COVID that bore a positive statistical relationship to the rise in pollutants related to the waiver. ${ }^{4}$ The enforcement waiver, entered ostensibly to protect workers from the novel coronavirus, likely caused a larger increase in public health impacts. Congressional investigators are linking this to particularly hard impacts on minority communities, creating environmental justice concerns. ${ }^{5}$

Emergency waivers from health and safety laws are too easy to get and are abused. As climate induced disasters increase emergency situations, their use, and thus abuse, may become more and more common. Public health impacts in turn may be even worse than can be predicted as public health menaces related to climate change interact synergistically. As the attention on the COVID environmental enforcement waivers make clear,

1. Ellen Knickmeyer et al., Thousands Allowed to Bypass Environmental Rules During Pandemic, AssociATED PRESS (Aug. 24, 2020), https://apnews.com/3bf753f9036e 7 d88f4746bla36clddc4 [https://perma.cc/D6DM-U3YU].

2. Sean Reilly, Air Pollution linked to 9\% Higher Virus Death Rate, GREENWIRE (Sept. 11, 2020), https://www.eenews.net/greenwire/2020/09/11/stories/1063713515 [https:// perma.cc/5XL2-YBTK.

3. Sean Reilly, Study of Emissions and Virus Deaths Implicates EPA Policy, GREENWIRE (Jul. 17, 2020), https://www.eenews.net/greenwire/2020/07/17/stories/10635 80943 [https://perma.cc/XA23-SGDZ].

4. Id.

5. Kelsey Brugger, Feud with Democrats escalates over enforcement plans, GREENWIRE (Apr. 23, 2020), https://www.eenews.net/greenwire/2020/04/23/stories/10629 52295 [https://perma.cc/6VE8-6RDC]. 
we need to rethink these emergency waivers and disasters, or we will wind up with more harm towards more vulnerable people for the benefit of shareholders.

\section{EMERGENCY WAIVER ABUSES AND HARM - LESSONS FROM THE LAST THREE YEARS}

\section{A. Hurricane Harvey}

On August 23, 2017, Texas Governor Greg Abbott declared a state of disaster as Hurricane Harvey approached the Texas Gulf Coast. ${ }^{6}$ In September 2017, the state of disaster was ultimately expanded to sixty Texas counties. Governor Perry was continuing to renew this declaration as of October 7, 2020 - over three years after Hurricane Harvey hit. ${ }^{7}$

Emergency disaster declarations in Texas (as in many states and for the federal government) allow the governor to unilaterally suspend specific rules and regulations if they would hinder disaster recovery. ${ }^{8}$ Pursuant to the Harvey emergency, the Texas Commission on Environmental Quality (TCEQ) formally requested Governor Abbott to suspend dozens of environmental rules on August 28, 2017, as Hurricane Harvey was breaking rain records in Houston and the Texas Gulf Coast area. ${ }^{9}$

The waiver requested suspension of air quality rules during the emergency related to emission "upset" events as well as suspension of the monitoring and release of unpermitted Volatile Organic Compounds. ${ }^{10}$ As required for a request for emergency waivers, the request indicated why it was necessary given immediate Hurricane Harvey and hurricane recovery efforts. Specifically, the TCEQ's request noted that environmental law compliance on air and water pollution:

6. Governor of Texas, Proclamation Declaring State of Disaster Under Section 418.014 of the Tex. Government Code (Aug. 23, 2017), https:/gov.texas.gov/uploads/files/press/ Governor_Abbott_Declares_State_of_Disaster_For_30_Texas_Counties.pdf [https://perma.cc/ S5KM-KHND.

7. Governor Greg Abbott Renews the State Disaster Declaration for Counties Impacted by Hurricane Harvey, OFFICE OF THE TEXAS GOVERNOR, Oct. 7, 2020, https:// gov.texas.gov/news/post/governor-greg-abbott-renews-the-state-disaster-declaration-forcounties-impacted-by-hurricane-harvey [https://perma.cc/W4ST-MGPY].

8. TeX. Gov'T CODE $\S 418.012$; TeX. Gov'T CODE $§$ 418.014; TeX. Gov'T Code $\S 418.016$ (LexisNexis 2019).

9. Request for Suspension of TCEQ Rules (Aug. 28, 2017), https://www.tceq.texas.gov/ assets/public/response/hurricanes/suspension-of-tceq-rules-8.28.17.pdf [https://perma.cc/ ZJP7-LLKP.

10. Id. 
... may not be possible as a result of hurricane effects, such as lightning, floods, fires, wind or wind-blown damage, and power outages [;] and suspending these requirements would remove a potential impediment to disaster response. 11

However, these waivers stayed in place long after direct effects of Hurricane Harvey (lightning, floods, fires, wind, or wind-blown damage) had passed, and electricity had been restored. Most of the Gulf Coast region, including Harris County had dried out within 4 weeks and electricity was mostly restored within days. ${ }^{12}$

Despite this, Governor Abbott did not end the emergency waiver of these air and water pollution environmental rules until April 6, 2018, over 8 months after Hurricane Harvey hit. During this time, investigators from news organizations and NGOs discovered over 100 toxic pollution releases. ${ }^{13}$ According to the Houston Chronicle:

In all, reporters cataloged more than 100 Harvey-related toxic releases - on land, in water and air. Most were never publicized. ${ }^{14}$

While some of these incidents happened during Hurricane Harvey itself, many others may have happened afterwards.

The public will probably never know the extent of what happened to the environment after Harvey," said Rock Owens, supervising environmental attorney for Harris County. "But the individual companies of course know. 15

When a disaster such as an unprecedented flooding happen in Houston, one of the nation's largest industrial hubs, the results can be particularly bad. According to Time:

11. Id. at 1 .

12. Ryan Maye Handy, Power outages reported in wake of Hurricane Harvey, Houston CHRON. (Aug. 30, 2017), https://www.chron.com/news/houston-weather/hurricane harvey/article/Houston-still-has-power-power-loss-for-hundreds-11968986.php [https://perma. cc/V597-8DAQ.

13. Alex Stuckey, Hurricane Harvey-caused water and air pollution likely far higher than residents realize, HousTON CHRON. (Aug. 16, 2018), https://www.chron.com/ news/science-environment/article/Harvey-pollution-13152511.php [https://perma.cc/ YG4D-7PPK.

14. Frank Bajak, Silent Spills, Part 1: In Houston and beyond, Harvey's spills leave a toxic legacy, HOUSTON CHRON., https://www.houstonchronicle.com/news/houston-texas/ houston/article/In-Houston-and-beyond-Harvey-s-spills-leave-a-12771237.php [https://perma.cc/ AEA4-HNXA].

15. Id. 
Any mass flooding event brings with it public health concerns about the spread of contaminants through the water, but Houston's industrial sector-heavy on oil, gas and chemicals - has experts particularly worried that extreme flooding has created conditions that could lead to environmental disaster. ${ }^{16}$

In addition to the suspension of environmental and health and safety requirements, reporting requirements were also suspended. ${ }^{17}$ Thus, the waiver of environmental, health and safety rules not only impacts public health, but keeps us from getting information to know the extent of the harm.

\section{B. The COVID Pandemic Strikes}

On March 18, 2020, the Texas Commission on Environmental Quality announced a policy offering regulated entities swift relief from enforcement policies based on unexamined claims that COVID made compliance with regulation and monitoring difficult or impossible. ${ }^{18}$ Shortly after, at the federal level, the EPA's Chief of Enforcement, Susan Bodine, issued a regulatory relief program with more cooperative enforcement and waivers of penalties ostensibly because of problems with monitoring and regulating during COVID. These waivers included routine compliance monitoring, integrity testing, sampling, laboratory analysis, training, and reporting or certification. ${ }^{19}$ The waiver was repealed effective August $31,2020,{ }^{20}$ even though the COVID positivity rate, COVID cases, and COVID deaths were much higher at this time than at the initiation of the waiver. ${ }^{21}$

Other states followed the EPA's lead. According to an Associated Press article examining these waivers, many states issued blanket waivers from enforcement and monitoring while almost all states fielded such requests. ${ }^{22}$ Again, ostensibly these were to protect people during COVID exposure risk. In its request to take advantage of the COVID waiver in Indiana, Marathon's

16. Justin Worland, Hurricane Harvey's Environmental Toll Will Only Get Worse, Time MAg. (AUG. 31 2017), http://time.com/4923245/hurricane-harvey-arkema-groupexplosion/ [https://perma.cc/NB3X-3Q5M].

17. Stuckey, supra note 13.

18. Sean Reilly, Texas Environment Chief Defends Plan Offering Polluters Help, E\&E News, (Apr. 6, 2020), https://www.eenews.net/eenewspm/2020/04/06/stories/1062 805101 [https://perma.cc/X2L8-S9TM].

19. Susan Parker Bodine, COVID-19 Implications for EPA's Enforcement and Compliance Assurance Program, U.S. EPA, WASHINGTON, D.C. 20460, https://www.epa. gov/sites/production/files/2020-03/documents/oecamemooncovid19implications.pdf [https://perma.cc/537Q-TV8J].

20. Id.

21. The COVID Tracking Project, US Daily Deaths, The AtLanTic MonThLy Group, https://covidtracking.com/data/charts/us-daily-deaths [https://perma.cc/CBL8-C6EG].

22. Knickmeyer et al., supra note 1. 
auditing and process manager wrote, "We believe that by taking these measures, we can do our part to slow the spread of the COVID-19 virus.",23

In Texas, by September 4, 2020, there had been over 200 requests for waivers- most from large petrochemical facilities. ${ }^{24}$ Importantly, many of these requests were to suspend leak inspection detection and repair (LDAR). LDAR is the only way to monitor whether or not there are leaks of hazardous air pollutants, which can expand if not corrected. As previously quoted in the Associated Press article, this author stated:

"The whole point of leak detection is to avoid people being harmed from a leak of toxic material," said Victor Flatt, environmental law professor at the University of Houston. "If you suspend leak detection, you don't even know if it's happening."25

\section{THE LAW GOVERNING EMERGENCY ENFORCEMENT WAIVERS}

During a disaster, government may need to take immediate actions to preserve life and public health as well as property. In such cases, government strives to have a system in place to alleviate legal liability when actions are designed to deal with a greater harm. Federal law contains multiple individual emergency provisions in statutes, and the Stafford Act generally allows the federal government to declare states of emergency. ${ }^{26}$ The Stafford Act grants many powers to the Federal Emergency Management Agency, including providing an exemption from National Environmental Policy Act (NEPA) for immediate response actions ${ }^{27}$ In addition to the Stafford Act, the National Emergencies Act and the Public Health Service Act can also provide broad authority to waive or alter laws. ${ }^{28}$

Individual federal environmental laws also contain waiver authority. For example, section 110(f) of the Clean Air Act allows the President to declare a national or regional emergency, which authorizes governors to suspend their state implementation plans for achieving air quality standards for up to four months. ${ }^{29}$ The Clean Water Act also contains several emergency

23. Id.

24. TEXAS COMMISSION ON ENVIRONMENTAL QUALITY, https://www.tceq.texas.gov/ response/covid-19/pending-permit-applications-during-covid-19-disaster [https://perma.cc/ Q4EK-MJYQ].

25. Knickmeyer et al, supra note 1.

26. Stafford Act, § 501(b), 42 U.S.C. § 5191(b) (2021).

27. $\S 5159 ; \S 7410$ (f)(1)-(4); 44 C.F.R. $\S 10.8$ (2016).

28. 50 U.S.C. $\S 1621$ (a) (2021); 42 U.S.C. $\S 247 d$ (2021).

29. 42 U.S.C.A. $§ 7410$ (f)(1)-(4)(West). 
exemptions, including waivers for "acts of God [or] an act of war," emergencies requiring expedited permit-processing by the Corp of Engineers, ${ }^{31}$ and allowances for exigent discharges of oil and other hazardous substances. ${ }^{32}$ Though these provisions make it evident that Congress intended to provide some flexibility to states as they adapt to pending emergencies, the provisions make it equally clear that there are reasonable limitations on this flexibility.

However, given the "cooperative federalism" model for environmental laws, state laws governing emergencies and emergency waivers have even more impact on environmental protection. Most state disaster waiver laws use language that seem to limit disaster waivers during times of emergency or crisis. ${ }^{33}$ However, depending on the state's definition of emergency, disaster waiver process, and the EPA's accommodation of the state's disaster waiver, locations can technically still be in emergency situations even if those situations arguably no longer hinder the enforcement of environmental and health and safety laws.

The laws seem clear. For example, in Texas, under the Texas Disaster Act of 1975, the governor may "suspend the provisions of any regulatory statute" prescribing state or agency procedure if "strict compliance" with its provisions, orders or rules would "in any way prevent, hinder, or delay necessary action in coping with the disaster." 34 Though written broadly, here the statutory language suggests that the executive's discretion is not completely unrestrained. It is true that the governor may suspend the provisions of any state or agency statute during an emergency, but it appears the governor may only do so if strict compliance with its provisions would "prevent, hinder, or delay" necessary action. ${ }^{35}$

Thus, theoretically, the governor of Texas should not be able to suspend an environmental provision unless strict compliance with the provision would result in some impairment of "necessary" action related to the emergency or disaster. However, what constitutes "necessary" emergency action at the local level amidst disaster has not been articulated. This lack of clarity leaves defining an emergency or disaster regarding environmental waivers to the discretion of the executive branch.

The state of California employs similar statutory language under the California Emergency Services Act (CEAS), which states:

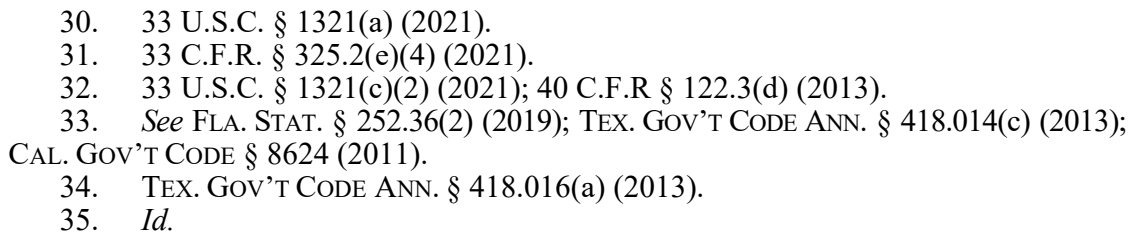


During a state of war emergency or a state of emergency the Governor may suspend any regulatory statute, or statute prescribing the procedure for conduct of state business, or the orders, rules, or regulations of any state agency. . . where the Governor determines and declares that strict compliance with any statute, order, rule, or regulation would in any way prevent, hinder, or delay the mitigation of the effects of the emergency. 36

The state of Florida's emergency waiver law is strikingly similar and provides that the governor may:

Suspend the provisions of any regulatory statute prescribing the procedures for conduct of state business or the orders or rules of any state agency, if strict compliance with the provisions of any such statute, order, or rule would in any way prevent, hinder, or delay necessary action in coping with the emergency. 37

In most of these largely populated states, notwithstanding their discretion ostensibly being limited by certain conditions, compliance with the time limitations is also a concern. In Florida, the emergency power of the governor is constrained by a time limit, as section 252.36(2) states:

\begin{abstract}
The state of emergency shall continue until the Governor finds that the threat or danger has been dealt with to the extent that the emergency conditions no longer exist and she or he terminates the state of emergency by executive order or proclamation, but no state of emergency may continue for longer than 60 days unless renewed by the Governor. The Legislature by concurrent resolution may terminate a state of emergency at any time. ${ }^{38}$
\end{abstract}

Texas has a time limitation on disaster declarations, requiring that disaster declarations go no more than thirty days unless renewed by the governor. ${ }^{39}$ However, the governor's determinations can be vetoed by the legislature. ${ }^{40}$ California also establishes a time limit of thirty days for state of war emergency powers, after which the emergency ends absent a special legislative session. ${ }^{41}$ In non-war emergencies, the governor must proclaim the emergency ended at the "earliest possible date that conditions warrant" or when a concurrent resolution of the California legislature declares its termination. ${ }^{42}$ Importantly, this language suggests that California's emergency statutes appear written to invite legislative approval for any continuations of states of emergency.

36. CAL. GOV'T CODE $§ 8571$ (1990).

37. Fla. STAT. § 252.36(5)(a) (2019); see also LA. STAT. ANN. § 724(d)(1) (2020).

38. FLA. STAT. § 252.36(2) (2019).

39. TEX. GOV'T CODE ANN. § 418.014(c) (2013).

40. § 418.013(c).

41. CAL. GOV'T CODE $§ 8624$ (2011).

42. CAL. Gov’t Code $\S 8629$ (1970). 
The problem is that these time limits in some cases are easily bypassed by extension, meaning that disaster declarations and emergency waivers have continued long after the emergency conditions that would make compliance difficult have ceased. For instance, in Texas, environmental waivers for Hurricane Harvey only ended after eight months, and as late as October 7, 2020, Governor Abbot renewed the Harvey Disaster.... ${ }^{43}$

The federal declaration of the COVID enforcement waivers demonstrates a similar pattern. The "waiver" was ostensibly designed to accommodate the need to social distance during the pandemic, but the waiver was lifted on August 31, $2020^{44}$ when COVID infections were peaking across the country. ${ }^{45}$ If in fact, the waiver was needed to accommodate emergency conditions, the rationale was undercut by its lifting, indicating the action was arbitrary and capricious in at least one of the determinations.

The definitions of states of "emergency" or "disaster" in local statutes are also so broad that they do not provide adequate limitations of executive power. For instance, in California, a state of "emergency" is defined as "the duly proclaimed existence of conditions of disaster ... or of extreme peril to persons and property ... caused by conditions such as ... air pollution, fire, flood, storm, epidemic, riot drought, cyberterrorism . . . likely to be beyond the control of the ... facilities of any single county. ..."46

This definition, though lengthy, does little in terms of limiting what may rise to the level of an emergency. In Florida,' a disaster is defined as "any natural, technological, or civil emergency that causes damage of sufficient severity and magnitude to result in a declaration of a state of emergency", 47 and an emergency is defined as "any occurrence, or threat thereof ... which results or may result in substantial injury or harm to the population or substantial damage to. . property." 48 In Texas, disasters are defined as "occurrence[s] or imminent threat[s] of widespread or severe damage, injury, or loss of life or property ... resulting from any natural or man-made cause. $" 49$

43. Governor Greg Abbott Renews the State Disaster Declaration for Counties Impacted by Hurricane Harvey, OFFICE OF THE TEXAS GOVERNOR, Oct. 7, 2020, https://gov. texas.gov/news/post/governor-greg-abbott-renews-the-state-disaster-declaration-forcounties-impacted-by-hurricane-harvey [https://perma.cc/W4ST-MGPY].

44. Susan Parker Bodine, COVID-19 Implications for EPA's Enforcement and Compliance Assurance Program, Addendum on Termination, U.S. EPA, WASHINGTON, D.C. 20460, https://www.epa.gov/sites/production/files/2020-06/documents/covid19addendum ontermination.pdf [https://perma.cc/27HL-NW4L].

45. See COVID Tracking Project, supra note 21.

46. CAL. GOV'T CODE $§ 8558$ (b) (2018) (emphasis added).

47. FLA. STAT. § 252.34(2) (2019).

48. FLA. STAT. $\$ 252.34(4)(2019)$

49. TeX. Gov'T CodE ANN. § 418.004(1) (LEXIS through 2019 Sess.). 
There have been recent cases seeking to curtail emergency declarations under the COVID epidemic, but these cases may not be equally applicable to waivers of enforcement and reporting requirements. ${ }^{50}$

The Michigan Supreme Court recently ruled that Governor Whitmer lacks the authority to declare an extended state of emergency or disaster under the Emergency Management Act of 1976 (EMA) or the Emergency Powers of the Governor Act from 1945 (EPGA). ${ }^{51}$ The Court addressed these two Acts separately as they pertain to the legitimacy of Governor Whitmer's attempted extension of the COVID state of emergency beyond the date of April 30, 2020, authorized by the legislature.

First, the Court held that the Governor's attempted extension of the emergency beyond twenty-eight days without legislative approval was beyond the authority of EMA, as EMA requires that the "governor shall issue an executive order declaring the emergency terminated, unless a request by the governor for an extension of the state of [disaster/emergency] for a specific number of days is approved by resolution of both houses of the legislature." 52 The Court next analyzed the EPGA, which more broadly authorizes the governor to promulgate "orders, rules, and regulations" which help to "bring the emergency situation ... under control," requiring only that such rules are "reasonable" and "necessary." ${ }^{.53}$ Although the Court conceded that the EPGA authorized the Governor to extend emergencies indefinitely, it held that the EPGA violated the Michigan Constitution because it "purport[ed] to delegate to the executive branch the legislative power of state government-including its plenary police powers." 54

Michigan's highest court was not alone in their view that extensions of COVID emergency restrictions require legislative authorization and cannot be unilaterally exercised with impunity by local officials, be they governors or administrators. In Wisconsin, Secretary Palm of the Department of Health Services (DHS) issued an order requiring all persons to remain home, prohibiting all travel, and requiring non-essential businesses to close. ${ }^{55}$ The Wisconsin Supreme Court held that the Emergency Order amounted

50. See e.g., Wisconsin Legis. v. Palm, 942 N.W.2d 900, 904 (Wis. 2020); In re Certified Questions from U.S. Dist. Ct., W. Dist. of Michigan, S. Div., 161492, 2020 WL 5877599 (Mich. Oct. 2, 2020).

51. In re Certified Questions, 2020 WL 5877599, at *24.

52. Id. at 16.

53. Id. at 16 (quoting the statutory language from MCL 10.31(1)).

54. In re Certified Questions, 2020 WL 5877599, at *24.

55. Wisconsin Legis. v. Palm, 942 N.W.2d 900, 904 (Wis. 2020). 
to a "rule" and was promulgated without following the emergency rulemaking procedures outlined in the Administrative Procedures Act. ${ }^{56}$

These cases articulate important points regarding local officials' extensions of emergencies. First, although emergency statutes may be broad in their authorization of executive power, this power is frequently limited in time and scope by the same statute. Second, even when statutory authority seems to authorize a local official's "indefinite" expansion of a given emergency, the statute may be unconstitutional if it infringes on the legislative's traditional plenary powers.

While this developing case law might address the open-ended emergency declaration issue, it is telling that it prohibits government action in response to the emergency as opposed to government waivers of inaction. Similarly, in both the states of Michigan and Wisconsin, where recent rulings curtailed the governors' powers to declare emergencies, there is divided government. In both states, the governorship is in Democratic hands while the legislature is in Republican hands. Although this does not mean that governor power will not be challenged (i.e., see Republican challenges to Texas Governor Abbot's COVID proclamations), disputes over emergency powers seem more likely to erupt in politically split states, leaving states with unified government less protected from unnecessary environmental enforcement waivers.

Even when implemented for appropriate reasons, waivers can still be abused by the regulated community, or simply be too broad in scope or in time. The very nature of being in an "emergency" lessens the thought and care that goes into waivers. The Obama administration EPA exercised enforcement discretion after Superstorm Sandy, ${ }^{57}$ and though these enforcement waivers were not called out as underhanded attempts to help industry, multiple complaints emerged about public health impacts and how care should have been implemented. ${ }^{58}$

In summary, the current emergency waiver laws are not working properly. At worst, such waivers can provide a "cover" for lax enforcement, harming the public and giving a gift to industry, hopefully under the radar screen. Texas' emergency waiver after Hurricane Harvey, and the various COVID environmental enforcement waivers seem to fit this type. And even if this is not the intent, many are overbroad due to uncertainty, and they continue too long.

56. Id. at 905 .

57. Brugger, supra note 5.

58. Rand Strauss, Sandy's Environmental Impact: What Are Your Officials Doing?, HufFPOST (Jan. 30, 2013), https://www.huffpost.com/entry/sandys-environmentalimpact_b_2215254[https://perma.cc/MR7H-FUT8]. 


\section{WHY ENFORCEMENT DISCRETION IS NOT AS DANGEROUS AS SYSTEM-WIDE EMERGENCY WAIVERS}

While we have so far focused on the constraints on the state and federal governments regarding when emergencies can be declared, what can be waived, and for how long, it should also be noted that state and federal agencies have the general option of failing to take enforcement actions under the broad category of enforcement or prosecutorial discretion.

The principle of prosecutorial discretion grants prosecutors and regulators enormous power over whom they pursue charges or complaints against. ${ }^{59}$ In the federal environmental law context, however, some non-enforcement discretion may be practically and legally limited. With respect to permits and permit provisions, the major environmental law citizen suits allow "citizen enforcers" when neither the state nor the federal government takes action. The Clean Air Act provision states that

... . [A]ny person may commence a civil action on his own behalf against any person .... who is alleged to have violated (if there is evidence that the alleged violation has been repeated) or to be in violation of (A) an emission standard or limitation under this chapter or (B) an order issued by the Administrator or a State with respect to such a standard or limitation. . . .60

This citizen suit provision has been limited by case law doctrine. ${ }^{61}$ As stated in an earlier article:

In 1987, Congress shielded state enforcement of NPDES violations from citizens' suits if the alleged permit breaches were being 'diligently prosecuted.' Most courts have interpreted this 'diligent prosecution' bar broadly to preclude any citizen's suit based upon the same CWA violations alleged in an administrative action, not allowing such challenges 'merely because [the citizens] do not agree with the type or extent of punishment imposed.' This problem is exacerbated when many consent orders are not made public or could appear to be "sweetheart" deals. Thus, judicial relief in a citizen's suit challenge to an NPDES permit enforcement is an 'odd duck' indeed, and generally occurs only when the state specifically does not impose any penalty for the NPDES permit violation. This

59. Prosecutorial Discretion Law and Legal Definition, USLEGAL, https://definitions. uslegal.com/p/prosecutorial-discretion/ [https://perma.cc/435H- 52WM].

60. 42 U.S.C. § 7604(a); see also 33 U.S.C. § 1365.

61. Steven Russo, States, Citizens, and the Clean Water Act: State Administrative Enforcement and the Diligent Prosecution Defense, 4 N.Y.U. ENVTL. L.J. 211, 231 (1995). 
allows the states to lower standards strategically by taking minimal actions to prevent citizens' suits. 62

But as much of a bar as this can be to citizen's suits, it has not been applied when the agency takes no action. ${ }^{63}$ The permit shield is no bar to citizen suit actions if the state enforcement action does not specifically alter the terms of the permit itself. ${ }^{64}$ So in the situation we saw with the EPA and COVID environmental enforcement waivers, citizen suits might not be prevented with individual waivers outside of an agency specific action or statement to the contrary.

There is some relevant case law in terms of such agency non-enforcement pronouncements. In the Utility Air Regulatory Group v. the EPA, the Supreme Court struck down the EPA's "tailoring rule" for new greenhouse gas sources as not justified by an "exercise of EPA's enforcement discretion." The court stated:

Agencies exercise discretion only in the interstices created by statutory silence or ambiguity; they must always "give effect to the unambiguously expressed intent of Congress." 66

In so doing, the court explicitly noted the Administration's admission that merely "not enforcing" would still leave permitted sources vulnerable to citizen's suits under the Clean Air Act. ${ }^{67}$ According to the court:

EPA itself has recently affirmed that the "independent enforcement authority" furnished by the citizen-suit provision cannot be displaced by a permitting authority's decision not to pursue enforcement. 68

Therefore, such enforcement decisions must be more than lack of enforcement, they must be at least an attempt by an agency to alter or interpret legal norms through agency action under the Administrative Procedures Act (APA), sections 553 and 557. ${ }^{69}$ Actions subject to the APA's provisions must not be arbitrary or capricious, nor an abuse of discretion, and must also be in conformance with law. ${ }^{70}$

62. Victor B. Flatt, A Dirty River Runs Through It: The Failure of Enforcement in the Clean Water Act, 25 B. Coll. EnVTL. AfF. L. REV. 1, 20 (1997) (citations omitted)

63. Citizens for a Better Env’t v. Union Oil Co., 83 F.3d 1111, 1119-20 (9th Cir. 1996).

64. Id. at $1115-17$.

65. Util. Air Reg. Group v. E.P.A., 573 U.S. 302, 321 (2014).

66. Id. at 326 (quoting Nat'l Ass'n of Home Builders v. Defenders of Wildlife, 551

U.S. $664(2007))$

67. Id.

68. Id. at 327.

69. Administrative Procedure Act $\S 706,5$ U.S.C. $\S 1009$ (e) (2012)

70. Administrative Procedures Act $\S 706$. 
General exercise of categorical enforcement discretion has been ruled permissible for agency action. But a recent Supreme Court Case concerning DACA illustrates potential limits placed on agencies' use of policy wide enforcement discretion. ${ }^{71}$ In this case, the Department of Homeland Security attempted to rescind DACA in response to the Attorney General's determination that certain benefits of the DACA program were illegal, and the DHS was legally bound by the determination. ${ }^{72}$ However, the Court reasoned that, because the eligibility and protection from deportation (forbearance) benefit components of DACA were distinguishable, the DHS acted arbitrarily and capriciously by not providing reasonable justification for why it did not retain the forbearance component. ${ }^{73}$ The Court further explained that, although the DHS's Acting Secretary clearly recognized her discretionary authority in "winding down the program," she did not appear to understand the scope of her discretion. ${ }^{74}$ Because DHS and its acting Secretary failed to provide an explanation of the scope of its enforcement discretion, and failed to exercise that discretion reasonably, recission of DACA was unreasonable. This suggests that when an agency is utilizing its enforcement discretion, it must be careful to provide well-articulated reasons, particularly if the non-enforcement decision infringes on legitimate legislative objectives.

However, with COVID and emergency waivers for environmental laws generally, there would always be the citizen suit provision which would make that inapplicable.

\section{WHAT SHOULD BE DONE?}

The specific laws, and the general enforcement discretion, are too broad in application and too ill planned before their use. A solution would be to curtail discretion and to require better planning ahead of time. There must be limits to emergency suspensions of environmental, health, and safety rules. Regulated parties should have as much incentive as possible to prepare for and control emission releases during disasters, and data concerning releases should continue to be gathered to the extent possible. Careful planning is paramount as disasters are likely to continue increasing in the face of climate change.

71. Dept. of Homeland Sec. v. Regents of the U. of California, 140 S. Ct. 1891 (2020).

72. Id. at 1910 .

73. Id. at 1899 .

74. Id. at $1910-11$. 
There are several possible solutions at the federal level and state level.

\section{A. Pre-planning Before Disaster}

To avoid extensive environmental non-compliance and harm, even with well-intentioned disaster waivers, disaster and pre-disaster preparation is critical. The EPA could require facilities permitted under the Clean Air Act, Clean Water Act, and Resource Conservation and Recovery Act to plan for how they can best control emissions or avoid upset emissions when a disaster or emergency occurs. This could be accomplished with new rulemaking or guidance.

The Emergency Planning and Community Right to Know Act (EPCRA) provides a template for this requirement. The EPCRA requires the EPA administrator to compile a list of hazardous substances and their amounts, which when present at a facility, trigger the requirement to plan for an emergency. As a condition of their permits, all permitted CAA, CWA, and/or RCRA sources could be required to also plan for an emergency or disaster, or this requirement could be limited to a subset of major sources above a certain threshold amount of emissions.

The Clean Air Act was amended in 1990 to require "an accidental release prevention" program, to prevent chemical disasters with air toxics. ${ }^{75}$ This could be expanded to all permitted air sources above a certain thresh-hold criterion. Limiting or starting with the subset of largest sources also would make the review of such plans more manageable by the implementing agency. Each source subject to the emergency and disaster planning could be charged an amount to cover the additional personnel necessary to timely review such plans. The EPA could start implementing basic regulations to determine minimum requirements for such plans.

\section{B. Limitation of Emergency Waivers During Disaster}

To avoid abuse of emergency waivers, the ability to use such waivers should be limited. Though states already appear to limit such waivers to the situations in which waivers are necessary to cope and recover from disasters, this power has been abused in multiple situations with impunity. States that have unified government lose whatever checks "legislative approval" or acquiescence might confer, leaving no route for citizens to check the emergency power abuse. After Hurricane Harvey, multiple organizations requested that the Texas Commission on Environmental Quality withdraw its waiver, but enforcing such requests requires extensive administrative action. A complainant would have to initiate a formal rulemaking or

75. 42 U.S.C.A. $\S 7412(r)$ (West 2020). 
enforcement request and then challenge a refusal to initiate such action as a violation of a state Administrative Procedure Act.

But even legal challenges pursuant to the APA is limited by case law concerning emergencies and emergency declarations themselves. Despite courts' reticence to second guess the executive branch's emergency declarations, and increased political polarization during the COVID pandemic, some such cases have been successful.

A more uniform answer would be to have federal limitations over emergency suspensions of federal laws administered through cooperative federalism. Although the actual emergency declarations seem to be an area in which federal interference would be problematic, some changes could occur through federal action. For instance, federal rules could help maintain record keeping which would help prevent unknown or untraceable environmental harms which occur during enforcement waivers. While record keeping requirements for federal environmental laws might still be suspended during a disaster, the EPA could promulgate a rule under its CAA, CWA, and RCRA power that specifies that to the extent possible, all permitted entities should keep records of releases during disaster suspensions and continue to report these to their permitting agency (whether the state or the federal government). Except during the most intense phase of an emergency, when personnel may need to evacuate, or power is not available, most companies are already keeping track of their releases. There is no reason they should not be required to report what they know.

For these same statutes, the EPA could clarify that a state's emergency suspension of environmental rules for federally based requirements (such as RCRA, CERCLA, the CWA, and CAA) will be subject to federal agency review. And such waivers should automatically sunset after a certain period of time, subject to the state demonstrating the continued inability of permitted parties to meet their obligations. Failure to do so could work as a revocation of the state's authority to continue administering that particular act.

It is true that the EPA has little appetite or capacity for state program takeovers ${ }^{76}$ but with an adequately funded EPA it would be possible. Additionally, the mere threat of a possible takeover can alter state actions. ${ }^{77}$ As noted in the introduction, the TCEQ's request for emergency waivers

76. Flatt, supra note 62, at 31.

77. See e.g., Matthew Tresaugue, Texas Seeks to Regain Control of Greenhouse Gas Permits, Hous. CHRON. (Apr. 18, 2013), https://www.houstonchronicle.com/news/ houston-texas/houston/article/Texas-seeks-to-regain-control-of-greenhouse-gas-4446604.php [https://perma.cc/8LRH-SVFM]. 
was purportedly based on active hurricane impacts or loss of power, but continued for over 8 months after the initial danger. A one-month (or even two week) sunset would have been effective as the emergency conditions would have passed any re-passage of such waivers would have appeared arbitrary and capricious. 